\title{
PENERAPAN PASAL 27 AYAT 3 UNDANG-UNDANG NO 19 TAHUN 2016 TENTANG INFORMASI DAN TRANSAKSI ELEKTRONIK TERHADAP TINDAK PIDANA PENCEMARAN NAMA BAIK MELALUI INTERNET SEBAGAI CYBERCRIME DI HUBUNGKAN DENGAN KEBEBASAN BEREKSPRESI
}

\author{
Supiyati \\ Fakultas Hukum, Universitas Pamulang \\ ratihfh@gmail.com
}

\begin{abstract}
The application of criminal law in order to provide protection from cybercrime, this law reinforces the existence of Indonesia as one of the countries that is serious in fighting cybercrime. In practice, this law has instead become a rule that limits the exercise of freedom of expression. This happens because the existence of Article 27 paragraph (3) which regulates criminal acts of defamation/defamation as part of cybercrime. Even though the act of humiliation has been clearly regulated in the Criminal Code. Criminal law policy against criminal acts of defamation in cyberspace, is actually a duplication of the Humiliation provisions stipulated in the Criminal Code, this is clearly contrary to the principles of lex scricta, and lex certa. Making the offense a humiliation as a cyber crime with a relatively heavier crime instead of giving a deterrent effect on freedom of opinion and expression. To abolish Article 27 paragraph (3) of the ITE Law is a choice that needs to be made by the Government by applying a balance of conditions for offense in the form of restoration of good name and applying compensation needs to be associated in the Criminal Code Bill related to the criminalization of acts of contempt.
\end{abstract}

Keywords: Offense, freedom of expression, cybercrime

\begin{abstract}
ABSTRAK
Penerapan hukum pidana guna memberikan perlindungan dari cybercrime, Undang-undang ini semakin mempertegas keberadaan Indonesia sebagai salah satu Negara yang serius dalam melawan cybercrime. Dalam prakteknya, Undang-undang ini malah menjadi aturan yang membelenggu pelaksanaan kebebasan berekpresi. Hal ini terjadi karena keberadaan Pasal 27 ayat (3) yang mengatur tindak pidana penghinaan/pencemaran nama baik sebagai bagian dari cybercrime. Padahal perbuatan penghinaan sudah di atur secara jelas di dalam KUHPidana. Kebijakan hukum pidana terhadap tindak pidana penghinaan di dunia maya, sesungguhnya merupakan duplikasi terhadap ketentuan Penghinaan yang diatur dalam KUHP, hal ini jelas bertentangan dengan prinsip lex scricta, dan lex certa. Menjadikan tindak pidana penghinaan sebagai tindak pidana siber dengan pidana yang relatif lebih berat bukannya memberikan deterrent effect terhadap kebebasan berpendapat dan berekspresi. Menghapus Pasal 27 ayat (3) dalam UU ITE adalah pilihan yang perlu dilakukan oleh Pemerintah dengan menerapkan keseimbangan kondisi atas tindak pidana penghinaan berupa pemulihan nama baik serta menerapkan ganti kerugian perlu diasosiasikan dalam RUU KUHP terkait dengan pemidanaan terhadap perbuatan penghinaan.
\end{abstract}

Kata kunci : Tindak pidana penghinaan, kebebasan berekspresi, cybercrime 


\section{PENDAHULUAN}

Peradaban dunia pada masa saat ini ditandai dengan fenomena kemajuan teknologi informasi dan globalisasi yang berlangsung hampir di semua sektor kehidupan. Perkembangan teknologi dan globalisasi tidak saja terjadi di negara maju, tetapi juga di negara berkembang. Saat ini teknologi informasi memegang peranan yang penting dalam perdagangan dan ekonomi antar negara-negara di dunia, termasuk memperlancar arus informasi. Teknologi informasi diyakini membawa keuntungan yang besar bagi negara-negara di dunia. (Suharyanto, 2013 : 1) Dalam Pasal 1 ayat (3) UndangUndang Dasar Negara Republik Indonesia Tahun 1945, telah ditegaskan bahwa negara Indonesia adalah Negara yang berdasarkan atas hukum.

Di era globalisasi saat ini teknologi yang sangat berkembang adalah teknologi internet. Pengembangan dan penggunaan perangkat teknis yang dapat membantu semua bentuk aktivitas manusia dalam bidang hiburan, pendidikan, perdagangan, pemerintahan dan komunikasi, itu merupakan hal yang wajar. Kemajuan teknologi informasi sekarang dan kemungkinan di masa yang akan datang tidak lepas dari dorongan yang dilakukan oleh perkembangan teknologi komunikasi dan teknologi komputer, sedangkan teknologi komputer dan telekomunikasi didorong oleh teknologi mikro elektronika, material, dan perangkat lunak. Perpaduan teknologi komunikasi dan komputer melahirkan internet yang menjadi tulang punggung teknologi informasi. Teknologi informasi diyakini membawa keuntungan dan kepentingan yang besar bagi Negara. Di era globalisasi ini teknologi yang sangat berkembang adalah teknologi internet. Perkembangan internet di Indonesia memang seperti tidak terduga sebelumnya. Beberapa tahun yang lalu, internet hanya dikenal oleh sebagian kecil orang yang mempuyai minat dibidang komputer.

Bangsa Indonesia yang sedang tumbuh dan berkembang menuju masyarakat industri yang berbasis teknologi informasi, dalam beberapa hal masih tertinggal. Kondisi ini disebabkan karena masih relatif rendahnya sumber daya manusia di Indonesia dalam mengikuti perkembangan teknologi informasi dan komunikasi ini, termasuk kemampuan dalam menghadapi masalah hukum yang timbul akibat penyalahgunaan teknologi informasi tersebut, yang menimbulkan terjadinya tindak pidana melalui internet (cybercrime). Cyber Crime merupakan salah satu bentuk atau dimensi baru dari kejahatan masa kini yang mendapatkan perhatian luas di dunia internasional (Arief, 2006 : 1). Perkembangan internet di Indonesia memang seperti tidak terduga sebelumnya. Beberapa tahun yang lalu, internet hanya dikenal oleh sebagian kecil orang yang mempunyai minat di bidang komputer. Namun, dalam tahuntahun terakhir ini penggunaan jasa internet meningkat secara sangat pesat, meski ada pendapat yang menyatakan bahwa kebanyakan penggunaan internet di Indonesia baru sebatas untuk hiburan dan percobaan. Pemanfaatan atau penyalahgunaan teknologi bukan hanya merupakan sebuah bentuk utama aktifitas manusia tetapi juga merupakan cara beraktifitas dalam bidang apapun. Sejak diakuinya pernyataan bahwa aktifitas manusia dalam berbagai bentuknya yang telah menyebabkan kemunculan dan aplikasi hukum atau pembuatan beberapa standar untuk mengatur aktifitas tersebut, nampak jelas bahwa teknologi juga harus dibuka agar dapat diatur oleh hukum. Salah satu penyalahgunaan internet adalah pencemaran nama baik yang dilakukan seseorang terhadap pihak lain. Hal atau keadaan yang dikomunikasikan atau dipublikasikan lewat internet dapat dikatakan merupakan penghinaan atau pencemaran nama baik bila hal atau keadaan itu adalah tidak benar bagi pihak yang menjadi korban, baik itu merupakan itu yang merusak reputasi ataupun yang membawa kerugian material bagi pihak korban.

Salah satu penyalahgunaan internet adalah pencemaran nama baik yang dilakukan seseorang terhadap pihak lain. Hal atau keadaan yang dikomunikasikan atau dipublikasikan lewat internet dapat dikatakan merupakan penghinaan atau 
pencemaran nama baik bila hal atau keadaan itu adalah tidak benar bagi pihak yang menjadi korban, baik itu merupakan itu yang merusak reputasi ataupun yang membawa kerugian material bagi pihak korban. Saat ini telah ada beberapa regulasi dalam hukum positif Indonesia di bidang teknologi informasi diantaranya Undangundang No 19 Tahun 2016 perubahan atas Undang-undang No 11 Tahun 2008 Tentang Informasi dan Transaksi Elektronik. Demikian juga Indonesia, dimana pengguna teknologi informasi berkembang dengan sangat cepat dan semakin penting artinya bagi masyarakat. Pemanfaatannya pun semakin meluas sehingga memasuki semua segi kehidupan. Undang-undang No. 19 Tahun 2016 perubahan atas Undangundang No 11 Tahun 2008 Tentang Informasi dan Transaksi Elektronik dalam era globalisasi informasi telah menempatkan Indonesia sebagai bagian dari masyarakat informasi dunia sehingga mengharuskan dibentuknya pengaturan mengenai pengelolaan informasi dapat dilakukan secara optimal, merata dan menyebar keseluruh lapisan masyarakat.

Bangsa Indonesia yang sedang tumbuh dan berkembang menuju masyarakat industri yang berbasis teknologi informasi, dalam beberapa hal masih tertinggal. Kondisi ini disebabkan karena masih relatif rendahnya sumber daya manusia di Indonesia dalam mengikuti perkembangan teknologi informasi dan komunikasi ini, termasuk kemampuan dalam menghadapi masalah hukum yang timbul akibat penyalahgunaan teknologi informasi tersebut, yang menimbulkan terjadinya tindak pidana melalui internet (cybercrime).

Yang merupakan suatu teknologi yang berisikan kumpulan informasi yang dapat diakses oleh semua orang dalam bentuk jaringan-jaringan komputer yang disebut jaringan internet. (Mahayana, Menjemput Masa Depan, Fururistik dan Rekasayasa Masyarakat Menuju Era Global, 2000 : 24-25) Saat ini dapat dikatakan bahwa media internet di Indonesia tidak ubahnya seperti rimba raya yang tidak mempunyai aturan hukum, seseorang dapat saja menghujat, menghina, mencaci maki dan merusak nama baik pihak lain tanpa takut akan adanya tindakan hukum. Maka barubaru ini pemerintah Indonesia telah membuat dan menetapkan peraturan hukum yang mengatur tentang Informasi dan Transaksi Elektronik dalam suatu bentuk peraturan perundang-undangan No. 19 Tahun 2016 perubahan atas Undang-undang No. 11 Tahun 2008 tentang Informasi dan Transaksi Elektronik.

Salah satu penyalahgunaan internet adalah pencemaran nama baik yang dilakukan seseorang terhadap pihak lain. Hal atau keadaan yang dikomunikasikan atau dipublikasikan lewat internet dapat dikatakan merupakan penghinaan atau pencemaran nama baik bila hal atau keadaan itu adalah tidak benar bagi pihak yang menjadi korban, baik itu merupakan itu yang merusak reputasi ataupun yang membawa kerugian material bagi pihak korban. Publikasi atau komunikasi tentang dari pihak lain dapat dikatakan pencemaran nama baik atau penghinaan, baik dilakukan dengan kata-kata atau tulisan yang terang-terangan maupun dengan bentuk yang tersembunyi namun mengandung konotasi merusak reputasi seseorang atau suatu badan.

Saat ini telah ada beberapa regulasi dalam hukum positif Indonesia di bidang teknologi informasi diantaranya Undangundang No 19 Tahun 2016 perubahan atas Undang-undang No 11 Tahun 2008 Tentang Informasi dan Transaksi Elektronik. Demikian juga Indonesia, dimana pengguna teknologi informasi berkembang dengan sangat cepat dan semakin penting artinya bagi masyarakat. Pemanfaatannya pun semakin meluas sehingga memasuki semua segi kehidupan. Undang-undang No. 19 Tahun 2016 perubahan atas Undang-undang No 11 Tahun 2008 Tentang Informasi dan Transaksi Elektronik dalam era globalisasi informasi telah menempatkan Indonesia sebagai bagian dari masyarakat informasi dunia sehingga mengharuskan dibentuknya pengaturan mengenai pengelolaan informasi dapat dilakukan secara optimal, merata dan menyebar keseluruh lapisan masyarakat.

Selain itu kemajuan teknologi juga mempermudah dan mempercepat komunikasi secara elektronik di dalam satu 
Negara, bahkan juga antar Negara. Peristiwa-peristiwa yang terjadi didunia dapat di ketahui hanya dalam hitungan menit melalui jaringan internet. Transfer uang antar bank dengan menggunakan $e$ cash dari dalam negeri ke luar negeri dapat dilakukan lebih cepat. Perdagangan melalui internet atau yang dikenal dengan electronic commerce (E-Commerce) semakin meningkat. Pembayaran untuk pemesanan barang atau program komputer dapat dilakukan dengan menggunakan credit card. Artinya kemajuan teknologi menyebabkan dunia menjadi tanpa batas (borderles) dan meyebabkan perubahan sosial berlangsung secara cepat. (Suharyanto, 2013:2)

Dalam Undang-undang No. 19 Tahun 2016 perubahan atas Undang-undang No 11 Tahun 2008 Tentang Informasi dan Transaksi Elektronik dimuat ketentuanketentuan mengenai larangan melakukan perbuatan-perbuatan tertentu yang diancam dengan sanksi pidana bagi pelakunya. Tegasnya Undang-undang No. 19 Tahun 2016 perubahan atas Undangundang No 11 Tahun 2008 Tentang Informasi dan Transaksi Elektronik menerapkan beberapa perbuatan yang dapat dikriminalisasi sebagai tindak pidana siber dengan sanksi-sanksi nya. Setidaknya ada dua keuntungan yang dibawa dengan keberadaan teknologi informasi. Pertama, teknologi informasi mendorong permintaan atas produk-produk teknologi informasi itu sendiri. Kedua, memudahkan transaksi bisnis keuangan di samping bisnis-bisnis lainnya (Raharjo, 2002 : 1)

Kejahatan baru ini sangat berdampak pada dunia usaha. Banyak yang menganggap bahwa keberadaan KUHP tidak mampu menjangkau kejahatan baru tersebut, sehingga pemerintah menginisiasi lahirnya aturan tentang cybercrime. Berdasarkan dokumen yang ada, Undang-Undang Tentang Informasi dan Transaksi Elektronik (UU ITE) sudah dibahas sejak tahun 2003 dan baru pada 5 September 2005 Presiden Susilo Bambang Yudhoyono resmi menyampaikan usulan inisiatif pembahasan RUU ITE kepada DPR RI melalui surat Presiden No. R/70/Pres/2005.5 DPR RI menindaklanjutinya dengan membentuk Panitia khusus RUU ITE yang beranggotakan 50 orang dari 10 fraksi di DPR. Pada 18 Maret 2008 diadakan rapat pleno pansus RUU ITE untuk mengambil keputusan tingkat pertama terhadap naskah akhir RUU ITE dan menyetujui RUU ITE untuk dibawa ke pengambilan keputusan tingkat kedua. Hingga akhirnya pada rapat paripurna DPR tanggal 25 Maret 2008 RUU ITE ditetapkan menjadi Undang-undang, yang kemudian dikenal dengan Undang- Undang No. 11 Tahun 2008 tentang Informasi dan Transaksi Elektronik dan diundangkan dalam Lembaran Negara Republik Indonesia Tahun 2008 Nomor 58 (selanjutnya ditulis dengan UU ITE) Kehadiran undang-undang terkait dengan pengaturan cybercrime ini tentu saja sangat dibutuhkan dalam penegakan hukum pidana, terutama kejahatankejahatan yang memang lahir dari kehadiran teknologi tersebut. Pentingnya keberadaan undang-undang ini didukung dengan kenyataan bahwa kejahatan didunia maya menempatkan Indonesia sebagai negara peringkat pertama dengan tindak pidana dunia maya terbanyak, mengalahkan Ukraina yang sebelumnya menduduki posisi pertama.

Namun dalam tataran praktek, penegakan hukum pidana dengan Undang-undang Informasi dan Transaksi Elektronik ini ternyata menimbulkan masalah hukum bagi orang-orang yang menggunakan sarana teknologi informasi untuk menyampaikan kritik terhadap pemerintah berupa jeratan hukum pidana maupun jeratan sanksi lainnya (Abidin, 2014 : 25) tetapi juga mengatur perbuatan pidana tradisional berupa penghinaan yang menggunakan media teknologi informasi.

Kebebasan menyampaikan pendapat ini juga sangat identik dengan prinsip demokrasi suatu negara. Bahkan dapat dikatakan bahwa suatu demokrasi timbul karena adanya perbedaan pendapat, atau suatu negara muncul kerena adanya pendapat bersama. Negara seharusnya juga harus menghormati serta melindungi hak atas kebebasan menyatakan pendapat ini tanpa mengurangi sedikitpun.

Dalam praktik pelaksanaan Undangundang Informasi dan Transaksi Elektronik, muncul berbagai kasus dengan tuduhan 
penghinaan/pencemaran nama baik sebagai bentuk pengekangan terhadap kebebasan berekspresi. Berbagai kasus tersebut berujung pada pelaporan ke polisi, tindakan penahanan dan pemenjaraan. Salah satu kasus yang menimpa seorang ibu rumah tangga di Makassar Undangundang Informasi dan Transaksi Elektronik kembali menjerat korban. Kali ini, giliran seorang ibu bernama Yusniar di Makassar ditahan karena dianggap telah melakukan pencemaran nama baik di internet. Berawal dari kisruh rebutan warisan yang telah berlangsung lama dan mulai memanas tahun ini, lalu ada aksi perusakan yang kemudian membuat Yusniar menuliskan tanggapannya di Facebook. Namun siapa sangka ucapan yang tak merujuk pada seseorang itu membuatnya dikenai tuduhan pencemaran nama baik oleh anggota DPRD Kabupaten Jeneponto bernama Sudirman Sijaya. Yusniar kini ditahan lebih dari 14 hari di tahanan Kejaksaan sambil menunggu sidang kedua.

Kasus lain yang menarik adalah Ustadz Adam Amrullah yang merupakan Trainer Ruqyah Syar'iyyah di Trans7, Adam Amrullah berhasil ditahan di Polsek Bekasi Selatan. Hal itu, kabarnya terkait dengan pencemaran nama baik Senkom yang disebut Adam sebagai underbow LDII. Senkom melaporkan Adam terkait video yang diunggah Adam di Youtube.

Beberapa kasus di atas setidaknya memberikan gambaran bagaimana Pasal 27 ayat (3) Undang-undang Informasi dan Transaksi Elektronik digunakan oleh aparat penegak hukum untuk melindungi reputasi pejabat atau penguasa setidaknya dibuktikan dari kasus-kasus tersebut di atas.

Keberadaan Pasal 27 ayat (3) Undangundang Informasi dan Transaksi Elektronik, telah pernah diuji Mahkamah Konstitusi. Pertimbangan dan putusan Mahkamah Konstitusi menyatakan bahwa secara harfiah unsur di muka umum, diketahui umum, atau disiarkan dalam Pasal 310 ayat (2) KUHP tidak dapat diterapkan dalam dunia maya, sehingga memerlukan unsur ekstensif yaitu mendistribusikan dan/atau mentransmisikan, dan/atau membuat dapat diaksesnya. Selain itu Mahkamah Konstitusi juga menyatakan bahwa pasal-pasal tertentu dalam KUHP dianggap tidak cukup memadai untuk menjawab persoalanpersoalan hukum yang muncul akibat aktivitas di dunia maya.

Setelah Putusan Mahkamah Konstitusi yang menyatakan tindak pidana penghinaan dalam KUHP tidak dapat diterapkan dalam ranah dunia maya, ternyata dalam praktik penegakan hukum ada beberapa perkara penghinaan menggunakan media informasi elektronik yang divonis menggunakan ketentuan tindak pidana penghinaan dalam KUHP, diantaranya adalah Perkara Nomor 40/Pid.B/2012/PN.SRG di pengadilan negeri serang dengan Terdakwa Lelly Burhanuddin yang didakwa dengan Pasal 311 ayat (1) KUHP karena telah mengirimkan SMS ke Anggri Syariati yang isinya "Goblok, tahu bayar kah tidak katanya keluarga terhormat, keluarga terhomat tai". Atas dakwaan tersebut, Majelis Hakim menyatakan bahwa Terdakwa terbukti melakukan tindak pidana sebagaimana yang diatur dalam Pasal 311 ayat (1) KUHP.

Selain itu ada perkara di Pengadilan Negeri Rengat Kabupaten Kuantan Singingi Riau Nomor 53/Pid.B/2012/PN.RGT.TLK. Terdakwa Syamsuddin SPd. Telah mengirimkan SMS kepada Kepala Dinas Pendidikan, yang isinya "Ass. Pak. Saya Syamsuddin, Guru SMA Pangean yang peduli nasib guru di Kuansing yang sekarang lagi di obok-obok oleh setan sukarmis Pak." Oleh Penuntut Umum, Terdakwa hanya didakwa dengan Pasal 311 ayat (1) KUHP. Dua perkara di atas, setidaknya memberikan gambaran, bahwa tindak pidana penghinaan/pencemaran nama baik di media elektronik pun sebenarnya masih memungkinkan untuk dituntut dan diputus berdasarkan ketentuan yang ada di dalam KUHP, sehingga diperlukan aturan hukum lain yang mengatur hal tersebut.

\section{METODE PENELITIAN}

Dalam penelitian ini, penulis menggunakan metode penelitian yuridis normatif, yaitu suatu metode yang mana hukum di konsepsikan sebagai norma, kaidah dan asas atau dogma-dogma. Adapun penelitian yuridis menggunakan data sehingga pengumpulan data yang 
dilakukan dengan studi kepustakaan (library research), yaitu dengan melakukan penelitian terhadap bahan pustakaan, yang mencangkup tentang asas-asas hukum, dalam mengkaji persinggungan norma-norma dalam pasal 27 ayat (3) Undang-undang Informasi dan Transaksi Elektronik dengan norma yang berasal dari kajian filsafat dan teori hukum. Kegiatan yang dilakuka dalam analisis data penelitian normatif dengan cara data yang di peroleh, dianalisis secara deskriptif, kualitatif yaitu analisa terhadap data yang tidak bisa di hitung.

Dalam penelitian ini dilakukan secara deskriptif analisis, yaitu penelitian yang dilakukan dengan cara fakta-fakta baik dari data sekunder dan bahan hukum primer berupa peraturan perundangundangan seperti kitab Undang-undang Hukum Pidana (KUHP), Undang-undang Nomor 19 Tahun 2016 tentang perubahan atas Undang-undang Nomor 11 Tahun 2008 tentang Informasi dan Transaksi Elektronik, dan sebagainya. Penelitian hukum dapat dilihat dari sumber data maupun tujuannya. Dilihat dari sumber datanya, penelitian ini dikategorikan sebagai penelitian hukum normatif karena hanya menggunakan data sekunder. Mengingat penelitian ini merupakan penelitian hukum normatif, maka data yang digunakan dalam penelitian ini hanya meliputi data sekunder. Data sekunder adalah data yang diperoleh dari bahan-bahan kepustakaan. Data sekunder dalam penelitian ini terdiri dari bahan hukum primer dan bahan hukum sekunder.

\section{PERMASALAHAN}

Berdasarkan latar belakang yang di paparkan, maka penulis merumusakan masalah bagaimanakah penerapan Undang-undang No 19 Tahun 2016 tentang Informasi dan Transaksi Elektronik terhadap tindak pidana penghinaan /pencemaran nama baik melalui internet sebagai cybercrime dan bagaimana peranan Badan Cyber Nasional dalam memberikan perlindungan hukum terhadap kebebasan berekspresi melalui internet?
PEMBAHASAN

Penerapan Undang-Undang No 19 Tahun 2016 Tentang Informasi dan Transaksi Elektronik Terhadap Pencemaran Nama Baik di Internet

Alasan munculnya tindak pidana penghinaan dan atau pencemaran nama baik dalam Undang-undang Informasi dan Transaksi Elektronik, jika merujuk pada pembahasan di rapat kerja (Panja) DPR RI yaitu perlu memasukan seluruh tindak pidana yang dapat dilakukan menggunakan komputer atau jaringan komputer sebagai alat atau media, tentu kurang tepat. Seharusnya jika kita merujuk pada pendapatnya Barda Nawawi dalam hal kebijakan hukum pidana terkait dengan cybercrime, harusnya tetap berada dalam sistem hukum pidana (materil) yang saat ini berlaku di Indonesia. (Arief, Tujuan dan Pedoman Pemidanaan, 2012 : 45) Penentuan sanksi pun harus dilandasi oleh alasan-alasan yang dapat mendukung pilihan sanksi.

Sigid Suseno, Dosen Fakultas Hukum Universitas Padjajaran menjelaskan ketentuan Pasal 27 ayat (3) Undangundang Informasi dan Transaksi Elektronik merupakan ketentuan yang mengatur content related offence yaitu reformulasi tindak pidana yang terdapat dalam pasal-pasal Kitab Undang-undang Hukum Pidana. Untuk tindak pidana penghinaan khusus untuk perbuatan menyiarkan, mempertujukan atau menempelkan di muka umum dirubah menjadi mendistribusikan dan/atau membuat dapat diaksesnya dokumen elektronik yang bermuatan konten yang dilarang (Suseno, $2012:$ 166).

Apa yang dijelaskan oleh Sigid Suseno diatas, mempertegas bahwa sebenarnya tindak pidana penghinaan/pencemaran nama baik dalam pasal 27 ayat (3) Undang-undang Informasi dan Transaksi Elektronik tidaklah berbeda dari apa yang sebenarnya diatur dalam pasal 310 dan 311 Kitab Undang-undang Hukum Pidana. Dalam kajian formulasi kebijakan, maka terkait keberadaan Pasal 27 ayat (3) Undang-undang Informasi dan Transaksi Elektronik yang mengatur tindak pidana penghinaan merupakan kekeliruan, karena sejatinya ketentuan tersebut telah nyata dan tegas disebut dalam Kitab 
Undang-undang Hukum Pidana sebagai tindak pidana.

Ketidakadilan akibat gagalnya penyidik memahami Undang-undang Informasi dan Transaksi Elektronik, membuat kesalahan mendasar bisa di bedah, dalam pasal 27 ayat (3) Undangundang Informasi dan Transaksi Elektronik sesuai dengan putusan Mahkamah Konstitusi Nomor 50 Tahun 2008 adalah delik aduan (Klacht). Artinya sesuai dengan pasal 72 Kitab Undangundang Hukum Pidana, delik tersebut hanya bisa diadukan oleh orang yang menjadi korban dan tidak di wakilkan kecuali korban tidak cakap hukum (misalnya dibawah umur)

Putusan Mahkamah Konstitusi Nomor 50/PUU-VI/2008 menjelaskan bahwa penafsiran norma yang termuat dalam pasal 27 ayat (3) Undang-undang Informasi dan Transaksi Elektronik mengenai penghinaan dan/atau pencemaran nama baik, tidak bisa dilepaskan dari norma hukum pidana yang termuat dalam pasal 310 dan pasal 311 KUHP, sehingga konstitusionalitas pasal 27 ayat (3) Undang-undang Informasi dan Transaksi Elektronik harus dikaitkan dengan pasal 310 dan pasal 311 KUHP. Putusan Mahkamah Konstitusi tersebut menegaskan bahwa pasal 27 ayat (3) Undang-undang Informasi dan Transaksi Elektronik bukan sebuah norma baru karena harus absolute merujuk pasal 310 dan 311 KUHP. Sedangkan pasal 310 dan 311 KUHP sangat jelas disebutkan didalamnya terdapat unsur "agar diketahui oleh umum" dalam artian pencemaran nama baik menjadi pidana jika dimaksudkan agar diketahui oleh umum. Saat ini komisi I Dewan Perwakilan Rakyat dan Kemenrtrian Komunikasi sepakat untuk melakukan revisi terbatas Undangundang Nomor 11 Tahun 2008 tentang Informasi dan Transaksi Elektronik. Revisi tersebut sudah masuk dalam program legislasi nasional (Proglegnas) dan menjadi prioritas di tahun 2015, namun nasibnya hingga saat ini tidak jelas. Buktinya masih saja banyak yang dijerat dengan pasal 27 ayar (3) Undang-Undang Informasi dan Transaksi Elektronik.

Pengujian Undang-undang No 11 Tahun 2008 Pasal 27 ayat (3) jo Pasal 45 ayat (1), Pasal 27 ayat (3) telah melanggar asas lex certa dan kepastian hukum karena pasal 27 ayat (3) tidak dimuat dalam rumusan delik sejelas-jelasnya dan perumusan ketentuan pidana yang tidak jelas atau terlalu rumit hanya akan memunculkan ketidakpastian hukum.

\section{Penerapan Kitab Undang-Undang Hukum Pidana terkait dengan Pencemaran nama baik}

Pengaturan pencemaran nama baik dapat ditentukan pula dalam pasal 27 ayat (3) Undang-undang No 11 Tahun 2008 tentang Informasi dan Transaksi Elektronik (UU ITE). Ketentuan pasal tersebut melarang setiap orang dengan sengaja dan tanpa hak mendistribusikan dan/atau dokumen elektronik yang memiliki muatan penghinaan dan/atau pencemaran nama baik. Dalam UU ITE dijelaskan bahwa yang dimaksud informasi elektronik adalah satu atau sekumpulan data elektronik, termasuk tetapi tidak terbatas pada tulisan, suara, gambar, peta, rancangan, foto, electronic data interchange (EDI), surat elektronik (electronic mail), telegram, teleks, telecopy atau sejenisnya, huruf, tanda, angka, kode akses, simbol atau perforasi yang telah diolah yang memiliki arti atau dapat dipahami oleh orang yang mampu memahaminya.

Sedangkan dokumen elektronik merupakan setiap informasi elektronik yang dibuat, diteruskan, dikirimkan, diterima atau disimpan dalam bentuk analog, digital, elektromagnetik, optikal atau sejenisnya, yang dapat dilihat, ditampilkan dan/atau didengar melalui komputer atau sistem elektronik, termasuk tetapi tidak terbatas pada tulisan, suara, gambar, peta, rancangan, foto atau sejenisnya, huruf, tanda, angka, kode akses, simbol atau perforasi yang memiliki makna atau arti atau dapat dipahami oleh orang yang mampu memahaminya. Pengaruh yang ditimbulkan oleh teknologi informasi seperti telepon seluler terhadap kemudahan dan kemapuan mengelola informasi yang semakin mempersulit permasalahan yang timbul berkaitan dengan penaganan informasi. Oleh karena itu, permasalahan hukum yang timbul 
berkaitan dengan kemajuan dan perkembangan teknologi informasi perlu disikapi dengan menggunakan sudut pandang yang luas, yaitu dengan melihat berbagai dampak dan pengaruh yang mungkin ditimbulkannya. Namun demikian, Undang-Undang Informasi dan Transaksi Elektronik tidak menjelaskan lebih lanjut mengenai pengertian pencemaran nama baik. Oleh karena itu, pengertian pencemaran nama baik mengacu kepada pengertian pencemaran nama baik sebagaimana diatur dan dirumuskan dalam Pasal 310 KUHP dan Pasal 311 KUHP. Hal ini sesuai dengan konsekuensi rumusan Pasal 103 KUHP yang intinya menyatakan bahwa ketentuan-ketentuan dalam Bab I-VIII Buku I Kitab Undang-undang Hukum Pidana berlaku bagi perbuatan pidana yang diatur dalam peraturan perundangundangan pidana di luar Kitab Undangundang Hukum Pidana, kecuali ditentukan lain dalam peraturan perundang-undangan pidana yang bersangkutan. Penghinaan merupakan salah satu bentuk kejahatan yang diatur dalam Kitab Undang-Undang Hukum Pidana, terdapat pada Buku ke II mengenai kejahatan, khususnya Bab XVI, mulai dari Pasal 310 sampai Pasal 321 KUHP. Apabila dilihat dari jenis-jenis delik, maka penghinaan ini merupakan delik formal atau formeel delict.

Apabila yang dilakukan kejahatan pencemaran nama baik/pencemaran tertulis, dalam hal dibolehkan untuk membuktikan kebenaran apa yang dituduhkan, tetapi tidak membuktikannya dan tuduhan tersebut dilakukan bertentangan dengan apa yang diketahuinya, maka pelakunya diancam karena melakukan fitnah, dengan pidana penjara paling lama emapt tahun (Pasal 311 KUHP) (Moeljanto, 2007 : 114). Namun demikian, Undang-Undang Informasi dan Transaksi Elektronik (UU ITE) tidak menjelaskan lebih lanjut mengenai pengertian pencemaran nama baik. Oleh karena itu, pengertian pencemaran nama baik mengacu kepada pengertian pencemaran nama baik sebagaimana di atur dan dirumuskan dalam Pasal 310 Kitab Undang-undang Hukum Pidana dan Pasal 311 Kitab Undang-undang Hukum Pidana.
Hal ini sesuai dengan konsekuensinya rumusan pasal 103 Kitab Undang-undang Hukum Pidana yang intinya menyatakan bahwa ketentuan-ketentuan dalam Bab IVII buku I Kitab Undang-undang Hukum Pidana berlaku bagi perbuatan pidana yang diatur dalam peraturan perundangundangan pidana diluar Kitab Undangundang Hukum Pidana, kecuali ditentukan lain dalam peraturan perundang-undangan pidana yang bersangkutan.

R. Soesilo memberikan pendapat : (Soesilo, 1996 : 56) Menghina adalah suatu perbuatan pidana, karena penginaan merupakan kesengajaan untuk menyerang kehormatan atau nama baik seseorang yang diawali dengan adanya kesengajaan jahat atau niat jahat (criminal intent) agar orang lain terserang kehormatan atau nama baiknya. Jika terjadi, tindakan kritik yang didahului, disertai atau diikuti dengan perbuatan menghina, maka yang dipidana menurut hukum pidana bukan perbuatan kritiknya, melainnkan perbuatan penginaannya.

Untuk mengetahui kecenderungan putusan yang dijatuhkan oleh hakim dalam perkara pencemaran nama baik dapat ditelusuri melalui putusan pengadilan. Dalam perkara pidana pada umumnya dan perkara pencemaran nama baik pada khususnya kecenderungan putusan pengadilan dapat berbentuk putusan bebas (vrijspraak), putusan lepas dari segala tuntutan hukum (onslag van recht vervolging) dan putusan pemidanaan. (Harahap, 2000 : 326-333) Putusan bebas dijatuhkan oleh hakim apabila dari hasil pemeriksaan di sidang pengadilan, kesalahan terdakwa atas perbuatan yang didakwakan kepadanya tidak terbukti secara sah dan meyakinkan. Sedangkan putusan lepas dari segala tuntutan hukum dijatuhkan apabila pengadilan berpendapat bahwa perbuatan yang didakwakan kepada terdakwa terbukti, tetapi perbuatan itu tidak merupakan suatu tindak pidana. Selanjutnya putusan pemidanaan dijatuhkan apabila hakim berpendapat bahwa terdakwa bersalah melakukan tindak pidana yang didakwakan kepadanya.

Penggunaan Pasal 27 Ayat (3) Undang-undang Tentang Informasi 


\section{dan Transaksi Elektronik Untuk Menjerat Kebebasan Berekspresi}

Keberadaan Pasal 27 ayat (3) Undangundang Informasi dan Transaksi Elektronik adalah bentuk pasal karet lainnya, yang sangat efektif untuk membangun kebebasan berekspresi terutama bagi penggunamedia sosial, padahal, sebagai negara demokrasi, kebebasan berekspresi sebagai hak konstitusional warga negara, sebagaimana yang dijamin oleh Pasal 28E ayat (3) Undang-Undang Dasar 1945. Berikut ini adalah kasus-kasus yang berkaitan dengan Pasal 27 ayat (3) :

Kasus Ustadz Adam AmrullahTrainer Ruqiyah Syar'iyyah Trans7 (Perkara No. 1293 K/Pid.Sus/2015)

Ustadz Adam Amrullah di laporkan ke polisi atas pencemaran nama baik. Kasus ini bermula ketika Ustadz Adam Amrullah meng upload video berjudul nasehat Nasehat Adam Sekjen FRIH (Forum Rujuk Ilal Haq) dan tantangan Mubahalah kepada Imam/Ketua LDII. Video itu Ustadz Adam Amrullah upload ke youtube pada 24 April 2013, sehari setelah berita terdengar di Masjid Bogor, dimana Ustadz Adam Amrullah diundang MUI Bogor untuk menjelaskan bahwa LDII masih belum berubah dari ajaran Islam Jamaah. Video itu Ustadz Adam Amrullah upload ke youtube."

"Pada Agustus 2013 Ustadz Adam Amrullah mendapat surat somasi dari Senkom, isi somasinya, ada tayangan Senkom dari video tersebut, kalau nggak dicabut dan mendelete serta meminta maaf, maka akan dituntut. Melihat tanggalnya, dibuat sedemikian rupa maka surat somasi itu tidak bisa Ustadz Adam Amrullah cabut. Maka saya melaporkan LDII ke Kajaksaan Agung, beberapa hari Ustadz Adam Amrullah langsung diperiksa polisi, di BAP, dan lantas Ustadz Adam Amrullah jadi tersangka. Ternyata Kapolseknya memang LDII. Ada simpatisan dari Masjid Ramadhan mendukung Ustadz Adam Amrullah, mereka demo ke Polsek, terjadi kerusuhan. Ada dua simpatisan di tahan"“Ustadz Adam Amrullah sendiri tidak ditahan atas rekomendasi dari Majelis Mujahidin, dari Dewan Dakwah, dari FKUB, dari MUI Bekasi, semua meminta Ustadz Adam Amrullah tidak ditahan. Tim Pembelas Muslim (TPM) kemudian menjadi jaminan. Ustadz Adam Amrullah akhirnya tidak ditahan masuk sel, tapi hanya menjadi tahanan kota, sampai akhirnya kasusnya masuk persidangan".

Dalam kasus Ustadz Adam Amrullah diatas, Penuntut Umum mendakwa dengan Dakwaan Pasal 27 ayat (3) jo Pasal 45 ayat (1) Undang-Undang Republik Indonesia Nomor 11 Tahun 2008 tentang Informasi dan Transaksi Elektronik atau dakwaan kedua Pasal 310 ayat (1), ayat (2) KUHP.

Kasus Yusniar-Ibu Rumah Tangga (Perkara No.1939/ Pid.Sus/ 2016/ PN.Mks). Kali ini, giliran seorang ibu rumah tangga bernama Yusniar di Makassar ditahan karena dianggap telah melakukan pencemaran nama baik di internet. Berawal dari kisruh rebutan warisan yang telah berlangsung lama dan mulai memanas tahun ini, lalu ada aksi perusakan yang kemudian membuat Yusniar menuliskan tanggapannya di Facebook. Namun siapa sangka ucapan yang tak merujuk pada seseorang itu membuatnya dikenai tuduhan pencemaran nama baik oleh anggota DPRD Kabupaten Jeneponto bernama Sudirman Sijaya. Yusniar yang tidak menyebut siapa pun dalam statusnya di Facebook bisa dijerat dan bahkan kini ditahan lebih dari 14 hari di tahanan Kejaksaan sambil menunggu sidang kedua.

Damar Juniarto menuturkan kasus ini bisa menjadi bukti kuat pasal 27 ayat 3 di Undang-undang Informasi dan Transaksi Ellektronik begitu bersifat karet. Padahal, jika merujuk pada pasal 310 KUHP, jelas diatur bahwa pihak yang berperkara adalah orang yang disebut namanya. "Sekali lagi ini harus orang yang merasa dicemarkan namanya dan bukan institusi. Jadi tidak bisa diwakili atau bahkan tidak bisa mewakili institusi/organisasi".

Sementara dalam kasus Yusniar, kata-kata yang dipermasalahkan karena adanya ucapan yang menyinggung anggota DPR dan pengacara. "Siapa anggota DPR yang dimaksud Yusniar? Siapa pengacara yang dimaksud Yusniar? Kan sebetulnya tidak jelas", kata Damar melanjutkan. Oleh 
sebab itu, apabila Sudirman Sijaya yang melaporkan kasus ini merasa dirinya adalah orang yang dimaksud Yuniar, sebenarnya ada ada beberapa kejanggalan. Ucapan Yusniar yang menyebut kata "anggota DPR" tak sesuai dengan Sudirman karena Sudirman merupakan "anggota DPRD". Terlebih, tulisan Yusniar disimpulkan sendiri oleh pengadu. Hal itu yang harus dibuktikan lebih dulu oleh polisi saat penyelidikan. Kasus pencemaran nama baik ini berawal dari status Yusniar pada 14 Maret 2016 di Facebook. Namun unggahan itu dianggap telah mencemarkan nama baik Sudirman Sijaya yang kemudian melaporkan Yusniar ke Polres Tamalate pada 15 Maret 2016. Yusniar dikenakan pasal 27 ayat 3 Undang-undang Informasi dan Transaksi Elektronik dan pada 24 Oktober 2016 ia resmi ditahan kejaksaan Sejak Undang-undang Nomor 11 Tahun 2008 disahkan, kasus pidana penghinaan yang melibatkan pengguna internet di Indonesia mulai naik secara signifikan. Undang Undang yang mengatur tentang Informasi dan Transaksi Elektronik (ITE) tersebut memiliki rumusan karet khususnya pasal 27 ayat 3. Dalam pasal tersebut diatur "Setiap orang dengan sengaja dan tanpa hak mendistribusikan dan/atau mentransmisikan dan/atau membuat dapat diaksesnya informasi elektronik dam/atau dokumen elektronik yang memiliki muatan penghinaan dan/atau pencemaran nama baik dapat dipidana dengan penjara paling lama 6 (enam) tahun dan/atau denda paling banyak Rp 1.000.000.000,00 satu miliar rupiah".

"Pasal 27 ayat 3 Undang-Undang Informasi dan Transaksi Elektronik ancaman terbesar kebebasan berekspresi. Dari 20 kasus Pasal 27 ayat 3 UndangUndang Informasi dan Transaksi Elektronik yang diadili pengadilan, hanya delapan putusan yang pertimbangannya dianggap telah mengikuti kaidah hukum," bila melihat putusan pengadilan yang hanya delapan dianggap telah mengikuti kaidah hukum berarti mayoritas putusan belum menempatkan prinsip dasar hukum acara pidana dengan tepat. Lebih parahnya apabila seseorang dikenakan pasal 27 ayat 3 Undang-Undang Informasi dan Transaksi Elektronik tersebut sudah besar kemungkinan akan dianggap bersalah dan masuk penjara, ketika orang dikenakan pasal itu, 70 persennya sudah pasti masuk ke dalam penjara.

\section{Peranan Pemerintah Terhadap Kebebesan Berekspresi Dengan Badan Cyber Nasional Di era} perkembangan teknologi informasi, "perang" tak lagi menggunakan kekuatan fisik. Namun, perang bergeser menggunakan teknologi informasi dan data. Karena itu era teknologi dan informasi mengharuskan sebagian data dikemas dalam format digital. Isu persoalan siber nasional menjadi strategis, malahan berpotensi mengancam keamanan siber di Indonesia. Sebab, Indonesia memiliki sejumlah data negara yang bersifat rahasia termasuk data warga negara yang sepatutnya dilindungi. Penanganan dan pengawasan terhadap persoalan siber nasional masih bersifat sektoral, khususnya di lingkup kementerian dan kelembagaan. "Belum bersifat koordinatif dan belum adanya badan yang mengkoordinasikan secara integral.”

Pembentukan Badan Siber Nasional dapat menjadi sarana legitimasi pihak pemerintah. Undang-Undang no. 19 tahun 2016 tentang Informasi dan Transaksi Elektronik memang telah menjelaskan tentang hukuman apabila menyebarkan berita bohong. Akan tetapi, pemerintah tidak pernah secara spesifik mendefinisikan pengertian dari hoaks dan hate speech tersebut. Dengan tidak adanya pendefinisian yang jelas soal hoaks dan hate speech. Pembentukan Badan Siber Nasional merupakan sebuah bentuk intervensi pemerintah terhadap kebebasan berpendapat di dunia internet. Hal ini terlihat dari fungsi Badan Siber Nasional yang dapat melakukan pengawasan dan pengendalian di dunia internet. Lewat fungsi ini, Badan Siber Nasional nantinya dapat melakukan pengendalian terhadap konten-konten yang ada di dunia internet.

Badan Siber Nasional merupakan sebuah badan yang memayungi badan siber dari lembaga yang ada seperti Direktorat Cyber Crime di Kepolisian, Cyber Defence di Kementerian Pertahanan, dan Cyber Inteligence di Badan Inteligen Negara. Jadi, posisinya lebih tinggi dibandingkan badan-badan yang sudah ada. Di lihat dari segi relasi 
kekuasaan, maka posisi kekuasaan Badan Siber Nasional lebih kuat. Yang menjadi pertanyaan adalah bagaimana mekanisme pengawasannya. Oleh karena itu, pemerintah perlu menjelaskan lebih lanjut mengenai bentuk pengawasan. Sebenarnya, tanpa adanya Badan Siber Nasional pun, kebebasan berpendapat sudah dijamin. Dan, peraturan tentang potensi pelanggaran kebebasan berpendapat juga sudah ada sebelumnya Pada UUD 1945 Pasal 28 dijamin bahwa "Kemerdekaan berserikat dan berkumpul, mengeluarkan pikiran dengan lisan dan sebagainya ditetapkan dengan undangundang". Dasar ini merupakan jaminan bagi setiap warga negara Indonesia untuk bebas berpendapat dalam kehidupan sehari-harinya. Hak asasi adalah hak-hak yang bersifat dasar atau pokok (seperti hak hidup dan hak mendapat perlindungan). (Moeliono, 1989: 292)

Salah satu ciri negara hukum adalah adanya kebebasan berpendapat, kebebasan berorganisasi dan jaminan serta adanya perlindungan terhadap hak asasi manusia yang mengandung persamaan dalam bidang politik, sosial, ekonomi dan budaya. Indonesia yang telah menyatakan sebagai sebuah negara hukum, telah meratifikasi berbagai perjanjian Internasional yang bertujuan untuk tercapainya sebuah negara hukum. Indonesia merupakan negara hukum, sebagaimana yang telah ditegaskan dalam Undang-undang Dasar 1945 pasal 1 ayat (3) yang berbunyi negara Indonesia adalah negara hukum. Setiap negara yang menyatakan diri sebagai negara hukum, maka harus memenuhi segala persyaratan sebagai sebuah negara hukum. Indonesia sebagai sebuah negara hukum telah mendasarkan pada adanya konstitusional. Kebebasan berpendapat di muka umum baik lisan dan tulisan serta kebebasan untuk berorganisasi merupakan hak setiap warga negara yang harus diakui, dijamin dan dipenuhi oleh negara. Persamaan tidak berarti serupa atau bahkan mirip dipandang dari sudut jasmani dan rohani, bakat dan ciri masing-masing. Tetapi yang dimaksud disini adalah perbedaanperbedaan yang ada sejak manusia itu dilahirkan, seperti warna kulit, raut muka, ras dan suku bangsa tidak mempengaruhi hanya sebagai manusia. Membedakan mereka berdasarkan warrna, ras atau suku bangsa merupakan suatu penolakan dari persamaan ini dan juga merupakan ketidakadilan. (Leath Levin, 1987: 43)

Pasal 27 ayat (3) UU ITE jelas tidak menjelaskan apakah delik ini masuk dalam kategori Delik Aduan atau masuk dalam kategori Delik Biasa. Jika merujuk pada pendapat Ahli, Dr. Mudzakkir, SH, $\mathrm{MH}$, dalam sidang pleno pada 19 Maret 2009 yang pada pokoknya menerangkan bahwa kategorisasi delik reputasi sebagaimana dimaksud dalam Pasal 27 ayat (3) UU ITE sangat tergantung pada delik reputasi dalam KUHP yang di insert kedalamnya. Dengan kata lain apabila delik reputasi dalam KUHP yang di-insert adalah delik biasa maka kategorisasi delik pada Pasal 27 ayat (3) UU ITE adalah delik biasa namun jika delik reputasi dalam KUHP yang di-insert adalah delik aduan maka kategorisasi delik pada Pasal 27 ayat (3) UU ITE adalah delik aduan. Dalam pertimbangannya, Mahkamah Konstitusi langsung menyatakan bahwa Pasal 27 ayat (3) UU ITE masuk dalam kategori delik aduan, tanpa ada penjelasan teoritis bagaimana Mahkamah Konstitusi menemukan bahwa Pasal 27 ayat (3) masuk dalam kategori delik aduan.

Prinsip ini menekankan bahwa Negara sebaiknya mengkaji kerangka kerja hukum yang ada untuk dan lainnya, asal usul kebangsaan atau sosial, kewarganegaraan, kepemilikan, kelahiran atau status-status lainnya memastikan bahwa pembatasan kebebasan berekspresi mengikuti hal-hal di atas. Terkait dengan tindak pidana Penghinaan dan/atau Pencemaran Nama Baik Dalam UndangUndang Informasi dan Transaksi Elektronik, jika diuji dengan menggunakan three past test, maka:

1. Ketentuan pasal ini memiliki rumusan yang tidak jelas dan multitafsir, selain rumusan yang tidak jelas, unsur yang menjadi bestanddel delict nya pun tidak jelas, bahkan subjek yang dilindungi pun tidak jelas serta ketidakjelasan muatan penghinaan atau pencemaran nama baik yang diatur. 
2. Melindungi reputasi adalah kepentingan yang sah, namun kepentingan yang dilindungi dalam Pasal 27 ayat (3) kabur/tidak jelas, hal ini terlihat dalam rumusan pasal yang berbunyi “...yang memiliki muatan penghinaan dan/atau pencemaran nama baik" yang menjadi soal adalah, penghinaan dan atau pencemaran nama baik siapa? Individu, korporasi, pemerintah/ badan umum atau pejabat?

3. Ketidakjelasan kepentingan yang dilindungi mengakibatkan ketidakjelasan konten yang dibatasi. Sehingga jelas bahwa tidak dibutuhkan sebenarnya pembatasan terhadap hal tersebut.

Terkait dengan pilihan pemidanaan terhadap pencemaran nama baik sebagai bentuk perlindungan negara terhadap hak reputasi, memang tidak dilakukan oleh Indonesia sendiri, banyak negara yang memilih mempidana tindakan penghinaan, namun kecenderungan hukum Internasional menganggap pencemaran nama baik itu sebagai pelanggaran perdata. Pengalaman menunjukkan bahwa undang-undang perdata cukup mampu untuk melindungi nama baik dengan tetap mempertahankan masyarakat yang demokratis. Terkait dengan hal tersebut, Hukum Indonesia pun sebenarnya juga telah mengatur perbuatan penghinaan dapat dituntut melalui jalur perdata, dan banyak yang menggunakan jalur ini, namun sayangnya ketentuan pidana pun masih diberlakukan dan bahkan berlapis.

Kekhawatiran yang muncul setelah diterbitkannya Undang-Undang Informasi dan Transaksi Elektronik yang memuat delik penghinaan ini adalah pembatasan seseorang dalam melaksanakan kebebasan berpendapat. Hal ini sebenarnya tidak perlu terjadi mengingat bahwa hukm pidana tidak diterapkan sebagai upaya pencegahaan seseorang melaksanakan haknya, dalam hal ini melaksanakan kebebasan berpendapat, melainkan upaya refresif ketika seseorang yang melaksanakann kebebasan berpendapatnya tetapi melanggar hak dan reputasi orang lain. Perundang-undangan hukum pidana tidak mungkin diterapkan pada pers sepanjang professional, taat kepada kode etik jurnalistik dan dapat membuktikan kebenaran atas yang diberitakan. Dengan begitu banyaknya pengaturan tentang perlindungan akan kebebasan menyatakan pendapat yang diatur dalam peraturan perundangundangan Indonesia, jelaslah sudah bahwa Indonesia termasuk Negara yang menjunjung tinggi atas perlindungan dan penghormatan terhadap Hak Asasi Manusia. Hal ini akan tampak berbeda jika dibandingkan dengan ketentuan yang terdapat dalam Pasal 27 ayat (3) undangundang Informasi Transaksi Elektronik No 11 Tahun 2008 atas perubahan undangundang No 19 tahun 2016. Dalam undangundang Informasi Transaksi Elektronik khususnya Pasal 27 ayat (3) dianggap tidak mencerminkan akan perlindungan kebebasan berpendapat yang dimiliki seseorang, bahkan seolah-olah justru mengekang kebebasan menyatakan pendapat tersebut. (Riswandi, 2003:46)

\section{PENUTUP \\ Kesimpulan}

Penerapan Undang-Undang No 19 Tahun 2016 tentang Informasi dan Transaski Elektronik terhadap tindak pidana penghinaan/pencemaran nama baik melalui internet sebagai cybercrime yaitu membutuhkan penambahan kesempurnaan, terkait dengan semakin canggihnya modus kejahatan tindak pidana siber yang semakin berkembang pesat, undang-undang ini banyak menuai pro dan kontra dianggap tidak dapat menurunkan tindak kejahatan tindak pidana cyber secara signifikan sehingga memunculkan tudingan bahwa undangundang ini tidak berjalan secara efektif terutama dari aspek pidananya. Rumusan pasal 27 ayat (3) bisa menimbulkan ketidakpastian hukum karena amat rentan pada tafsir apakah suatu proses, pernyataan pendapat/pikiran merupakan kritik atau penghinaan. Ia menambahkan rumusan delik formil pasal 27 ayat 3 Undang-Undang Informasi dan Transaksi Elekronik (ITE) bersifat ambigu, kabur, serta terlalu luas sehingga merugikan hak konstitusional sebagaimanna dijamin dalam pasal $28 \mathrm{~F}$ Undang-Undang Dasar (UUD) 1945 . 
Peranan Badan Cyber Nasional dalam memberikan perlindungan hukum terhadap kebebasan berekspresi melalui internet yaitu masih bersifat sektoral, khususnya di lingkup kementerian dan kelembagaan. "Belum bersifat koordinatif dan belum adanya badan yang mengkoordinasikan secara integral." Badan Cyber Nasional bukan merupakan cara terbaik untuk menanggulangi pelanggaran kebebasan berpendapat seperti hoaks dan hate speech. Apabila badan ini dibentuk, hal ini akan menunjukkan bahwa pemerintah membuat keputusan dengan tergesa-gesa. Idealnya kebebasan berpendapat dalam kehidupan digital, dalam media sosial, diatur oleh masyarakat digital itu sendiri. Oleh karena itu, pemerintah perlu memikirkan kembali sebuah solusi lainnya yang dapat menyentuh akar permasalahan. Sebenarnya, tanpa adanya Badan Siber Nasional pun, kebebasan berpendapat sudah dijamin. Dan, peraturan tentang potensi pelanggaran kebebasan berpendapat juga sudah ada sebelumnya Pada Undang-Undang Dasar (UUD) 1945 Pasal 28.

\section{Saran}

Karena Undang-Undang ITE ini dirasa masih multi interpretasi, maka diperlukan kecermatan dan ketelitian bagi para penegak hukum untuk memperoleh pemahaman yang integral mengenai substansi dari UU tersebut sehingga tidak ada lagi pihak yang merasa dirugikan. Hak untuk berekspresi dan menyatakan pendapat termasuk dengan menggunakan sarana internet merupakan hak asasi manusia yang dijamin dan dilindungi sebagaimana yang ditentukan dalam Pasal 19 Deklarasi Hak Asasi Manusia dan Pasal 19 Kovenan Internasional Hak Sipil dan Politik, serta UUD RI 1945. Namun dalam pelaksanaannya dapat dilakukan pembatasan, dengan syarat yang ketat. Pembatasan tersebut dapat dilakukan terkait dengan pornografi anak, penyebaran kebencian, hasutan publik untuk melakukan genosida, dan advokasi nasional, ras atau agama yang bisa memicu hasutan diskriminasi, kekerasan atau permusuhan (hate speech). Terkait dengan pengaturan tindak pidana penghinaan/pencemaran nama baik di internet (Pasal 27 ayat (3) UU ITE)

Undang-Undang Informasi dan Transaksi Elektronik merupakan UndangUndang yang masih tergolong baru sehingga masih perlu perbaikanperbaikan (revisi) terkait dengan substansi/isinya. Sebagai bagian dari Negara-negara yang ada di dunia, Indonesia perlu melihat kecendrungan internasional yang sudah merubah pandangan bahwa pemenjaraan terhadap penghinaan merupakan bentuk pengekapan terhadap kebebaan berekspresi. Pilihan-pilihan menerapkan hukuman yang manusiawi dengan mengedapankan pengembalian keseimbangan keadaan adalah pilihan yang baik bagi penghormataan terhadap hak asasi manusia.

\section{DAFTAR PUSTAKA}

Agus Raharjo, Cybercrime: Pemahaman dan Upaya Pencegahan Kejahatan Berteknologi, Citra Aditya Bakti, Bandung, 2002

Anton M. Moeliono, Kamus Besar Bahasa Indonesia Tim Pusat Pembinaan dan Pengembangan Bahasa DEPDIKBUD, Ghalia Pustaka, Jakarta, 1989

Budi Agus Riswandi, Hukum Dan Internet Di Indonesia, UII Pres, Yogyakarta, 2003

Budi Suharyanto, Tindak Pidana Teknologi Informasi (Cybercrime) Urgensi Pengaturan dan Celah Hukumnya, PT. Raja Grafindo Persada, Depok 2013

Barda Nawawi Arief, Tindak Pidana Mayantara Perkembangan Kajian Cyber Crime di Indonesia, PT. Raja Grafindo Persada, Jakarta, 2006

Barda Nawawi Arief, Tujuan dan Pedoman Pemidanaan, Pustaka Magister, Semarang, 2012

Dimitri Mahayana, Menjemput Masa Depan, Fururistik dan Rekasayasa Masyarakat Menuju Era Global, Rosda, Bandung, 2000

Leath Levin, Hak-Hak Asasi Manusia Tanya Jawab, PT. Pradnya Paramita, Jakarta, 1987 
Moeljanto, Kitab Undang-Undang Hukum Pidana, Bumi Aksara, Jakarta, 2007

M. Yahya Harahap, Pembahasan Permasalahan dan Penerapan KUHAP Pemeriksaan Sidang Pengadilan, Banding, Kasasi dan Peninjauan Kembali, Sinar Grafika, Jakarta, 2000

R. Soesilo, Kitab Undang-Undang Hukum Pidana (KUHP) Serta KomentarKomentarnya Lengkap Pasal Demi Pasal, Politiea, Bogor, 1996
Sigid Suseno, Yuridiksi Tindak Pidana Siber, PT. Refika Aditama, Bandung, 2012

Wahyudi Djafar dan Zainal Abidin, Membelenggu Ekspresi: Studi Kasus Mengenai Praktik Pemblokiran/Penyaringan Konten Internet Dan Kriminalisasi Pengguna Internet di Indonesia, Elsam, Jakarta, 2014

Lihat Putusan Mahkamah Konstitusi pada perkara Nomor. 50/PUU-VI/2008 tentang uji materil Pasal 27 ayat (3) UU ITE 